\title{
ANALISIS PENILAIAN KINERJA PT. BANK BRI, TBK KANWIL MAKASSAR DENGAN PENDEKATAN BALANCE SCORECARD
}

\author{
A. Muara Arumbarkah \\ Dosen Prodi Manajemen, Universitas Muslim Indonesia \\ Email: muaraarumbarkah@umi.ac.id
}

(Diterima: 2 Februari 2019; direvisi: 10 Maret 2019; dipublikasikan: 09 April 2019 ) akses terbuka dibawah licenci CC BY-NC-4.0 (https://creativecommons.org/licenses/by-nc/4.0/ ).

\begin{abstract}
In certain periods, an assessment of a condition of the bank's financial statements is needed to determine the organization's performance and its level of health. In this measurement contains information about the amount of assets (assets) owned as well as liabilities and equity (own capital). Then it will also be illustrated the results of the business obtained by the bank as well as the expenses and costs incurred to obtain these results in a certain period. This study aims to analyze the performance of PT. Bank BRI, Tbk using the balanced scorecard approach which is reflected through four main perspectives, namely financial perspective, customer perspective, internal business perspective and growth and learning perspective. This study uses a case study approach supported by a survey that collects information about factors related to the research variable. With the Balance Score-card approach. Expected measurement model. This analytical method can provide accurate and detailed answers. The results of this study indicate that Financial Perspective (X3) is the most dominant variable influencing BRI Bank Performance $(Y)$ The relationship between variables $X$ and $Y$ is very strong indicating that the variable Financial Perspective, Customer Perspective, Internal Business Perspective \& Growth and Learning Perspective have influence a very significant (96.4\%) effect on BRI Bank Performance $(Y)$ while theoretical conclusions are all variables that have a significant effect.
\end{abstract}

Keywords: Balance Scorecard, Kinerja, The Performance of PT Bank BRI, Tbk.

\begin{abstract}
Abstrak: Pada periode dan masa tertentu, penilaian atas suatu kondisi laporan keuangan bank sangat dibutuhkan untuk mengetahui kinerja organisasi dan tingkat kesehatannya. Dalam pengukuran ini termuat informasi mengenai jumlah kekayaan (asset) yang dimiliki serta kewajiban dan ekuitas (modal sendiri). Kemudian akan tergambar pula hasil-hasil usaha yang diperoleh oleh bank serta beban dan biaya-biaya yang dikeluarkan untuk memperoleh hasil tersebut dalam satu periode tertentu.Penelitian ini memiliki tujuan untuk menganalisis kinerja PT. Bank BRI, Tbk dengan menggunakan pendekatan balanced scorecard yang di cerminkan melalui empat perspektif utama, yakni perspektif keuangan, perspektif pelanggan, perspektif bisnis internal dan perspektif pertumbuhan dan pembelajaran. Penelitian ini menggunakan pendekatan studi kasus yang didukung dengan survei yang mengumpulkan informasi mengenai faktor-faktor terkait dengan variabel penelitian. Dengan pendekatan Balance Score-card. Model pengukuran diharapkan Metode analisis ini dapat memberikan jawaban yang akurat dan terperinci. Hasil penelitian ini menunjukkan Perspektif Keuangan (X3) merupakan variabel yang paling dominan berpengaruh terhadap Kinerja Bank BRI (Y) Hubungan keeratan antar variabel X dan Y sangat kuat mengindikasikan bahwa variabel Perspektif Keuangan, Perspektif Pelanggan, Perspektif Bisnis Internal \& Perspektif Pertumbuhan dan Pembelajaran memiliki pengaruh yang sangat signifikan $(96,4 \%)$ berpengaruh terhadap Kinerja Bank BRI (Y) adapun kesimpulan teoritis adalah kesemua variabel berpengaruh signifikan.
\end{abstract}

Kata kunci: Balance Scorecard, Kinerja PT Bank BRI, Tbk 



\section{PENDAHULUAN}

Sistem perbankan adalah sistem yang terdiri dari lembaga, kegiatan usaha, serta cara dan proses pelaksanaan kegiatan usaha yang memungkinkan bank melaksanakan fungsinya dengan baik. Bank memberikan pelayanan dalam lalu lintas sistem pembayaran sehingga kegiatan ekonomi dapat berjalan dengan lancar. Dengan efisiensi, keamanan, dan kelancaran sistem pembayaran dari perbankan mampu membawa perekonomian menjadi lebih baik. Selain itu, bank juga berfungsi sebagai media dalam mentransmisikan kebijakan moneter yang dilakukan bank sentral karena kebijakan moneter sendiri bertujuan untuk menjaga stabilitas harga dan pertumbuhan ekonomi. Pada periode dan masa tertentu, penilaian atas suatu kondisi laporan keuangan bank sangat dibutuhkan untuk mengetahui kinerja organisasi dan tingkat kesehatannya. Dalam pengukuran ini termuat informasi mengenai jumlah kekayaan (asset) yang dimiliki serta kewajiban dan ekuitas (modal sendiri). Kemudian akan tergambar pula hasilhasil usaha yang diperoleh oleh bank serta beban dan biaya-biaya yang dikeluarkan untuk memperoleh hasil tersebut dalam satu periode tertentu (Kasmir, 2002).

Untuk menilai kinerja suatu organisasi termasuk perbankan dapat diukur dengan penggunaan rasio keuangan. Penilaian organisasi akan berpengaruh terhadap kemampuan bank dan loyalitas nasabah terhadap bank yang bersangkutan. Penggunaan rasio keuangan memang terasa begitu bermanfaat dalam menilai kondisi keuangan perusahaan perbankan namun untuk penilaian kinerja keuangan yang kompleks membutuhkan suatu instrumen yang lebih komprehensif. Kaplan dan Norton mencoba merancang suatu sistem pengukuran kinerja yang lebih komprehensif yang disebut dengan Balanced Score card dengan tujuan untuk menyediakan informasi mengenai pencapaian strategis organisasi kedalam seperangkat tolak ukur kinerja yang saling berhubungan. Balanced Scorecard merupakan suatu metode pengukuran kinerja yang tidak hanya mencerminkan pada kinerja keuangan saja, tetapi juga kinerja non keuangan. Aspek non keuangan mendapat perhatian yang cukup serius karena pada dasarnya peningkatan kinerja keuangan bersumber dari aspek non keuangan, sehingga apabila perusahaan akan melakukan pelipat gandaan kinerja maka fokus perhatian perusahaan akan ditujukan kepada peningkatan kinerja non keuangan, karena dari situlah keuangan berasal.

Pengukuran kinerja perusahaan ini dinamakan dengan nama Balanced Scorecard yang merupakan salah satu sistem pengukuran kinerja yang menerapkan visi dan strategi perusahaan, sehingga tercapainya keselarasan tujuan dan mendorong karyawan untuk bertindak yang terbaik bagi perusahaan. Pengukuran ini berusaha untuk membuat perpaduan pengukuran strategi yaitu pengukuran keuangan dan non keuangan, serta pengukuran internal dan pengukuran eksternal. Tujuan dari pengukuran tersebut adalah memperhitungkan keseimbangan antara pencapaian kinerja keuangan dan non keuangan, antara kinerja jangka pendek dan jangka panjang, serta antara kinerja yang bersifat intern dan bersifat ekstern.

Sebagai organisasi yang berperan penting dalam membangun sistem perbankan yang baik pada tahun 2015, PT Bank Rakyat Indonesia (Persero) Tbk meraih penghargaan sebagai "Bank of The Year 2015 Indonesia" dalam ajang Bank of The Year Awards 2015 dari The Banker. Penghargaan tersebut akan menjadi kado bagi perseroan dan seluruh karyawan. Penghargaan dari The Banker ini merupakan bukti nyata kerja keras BRI dalam memberikan layanan dan kinerja keuangan terbaik di Tanah Air. Dari catatan 2 laporan kinerja keuangan tahun terakhir mulai 2013 - 2015 Per triwulan II tahun 2014 Bank BRI mencatat laba bersih setelah pajak sebesar Rp11,72 T (bank only), atau naik sebesar 17,11\% year on year. Angka ini mempublikasikan kinerja keuangan triwulan II-2014 dengan konsisten menunjukkan trend pertumbuhan yang positif.“ Pencapaian laba bersih tersebut merupakan hal yang sangat positif di tengah kondisi politik dan ekonomi domestik yang kurang kondusif. Solidnya kinerja bisnis Bank BRI di atas, tercermin dari pertumbuhan kredit Bank BRI yang mencapai 17,19\% secara YoY, dari Rp 391,77 triliun pada triwulan II-2013 lalu menjadi Rp 459,13 triliun pada triwulan II-2014. Pertumbuhan kredit tersebut juga dibarengi dengan prinsip kehati-hatian sehingga tingkat kredit bermasalah (Non Performing Loan-nett) dapat dijaga di level 0,57\%.Dari sisi pendanaan, Bank BRI juga berhasil menumbuhkan Dana Pihak Ketiganya. per akhir triwulan II-2014 total Dana Pihak Ketiga Bank BRI mencapai Rp488,45 Triliun atau tumbuh $11,27 \%$ year on year, dengan kontribusi sumber dana murah (CASA) yang tetap 
dapat dijaga di level 57,3\%. Tidak hanya itu, pertumbuhan Tabungan (saving) Bank BRI masih lebih tinggi bila dibanding dengan rata-rata industri, yakni 14,49\% berbanding 10,12\%.

Berdasarkan latar belakang tersebut maka peneliti menentukan rumusan masalah yakni Apakah sosialisasi peraturan daerah tentang pajak rumah kos berpengaruh positif dan signifikan terhadap kepatuhan wajib pajak di Kota Makassar" ?

Pengukuran suatu kinerja perusahaan secara komprehensif mengandung informasi yang berkaitan dengan aspek finansial dan non finansial, balance scorecard sebagai suatu alat yang membantu untuk mengukur kinerja perusahaan baik secara finansial maupun non finansial mengandung 4 (empat) perspektif utama yakni, perspektif keuangan, perspektif pelanggan, perspektif bisnis internal dan perspektif pertumbuhan dan pembelajaran. Dalam penelitian ini keempat perspektif tersebut digambarkan sebagai variabel independen yang mempengaruhi variabel dependen yakni kinerja Bank BRI.

Berdasarkan uraian yang telah dijelaskan pada bab sebelumnya, maka kerangka konseptual dalam sebagaimana tampilan gambar 1 :

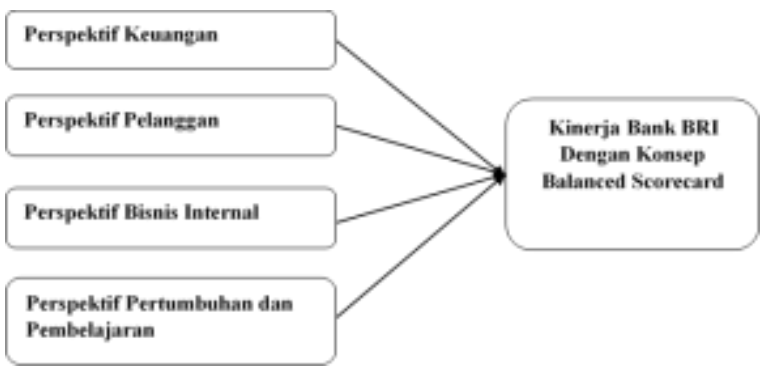

Gambar. 1. Model Kerangka Konseptual

Berdasarkan tinjauan pustaka dan kerangka konseptual yang diuraikan sebelumnya dapat dirumuskan hipotesis penelitian sebagai berikut :

1. Perspekstif keuangan berpengaruh signifikan terhadap kinerja PT. BRI tbk Kanwil Makassar.

2. Perspekstif pelanggan berpengaruh signifikan terhadap kinerja PT. BRI tbk Kanwil Makassar.
3. Perspekstif bisnis internal berpengaruh signifikan terhadap kinerja PT. BRI tbk Kanwil Makassar

4. Perspekstif pertumbuhan dan pembelajaran berpengaruh signifikan terhadap kinerja PT. BRI tbk Kanwil Makassar.

\section{METODE \\ Pendekatan Penelitian}

Pendekatan penelitian ini adalah studi kasus yang didukung dengan survei yang mengumpulkan informasi mengenai faktorfaktor terkait dengan variabel penelitian. Dengan pendekatan Balance Score-card. Model pengukuran diharapkan Metode analisis ini dapat memberikan jawaban yang akurat dan terperinci.

\section{Populasi dan Sampel}

Populasi dari penelitian ini adalah seluruh informasi perusahaan yang berkaitan mengenai pengukuran kinerja dengan pendekatan Balanced Scorecard (Sugiono, 2009). Informasi yang dimaksud yakni laporan keuangan, seluruh pelanggan, karyawan, dan aktifitas operasi PT BRI Kanwil, Tbk Makassar. Sampel dalam sebuah penelitian adalah sebagian dari jumlah dan karakteristrik yang dimiliki oleh populasi tersebut. Adapun jumlah sampel yang diambil adalah 25 responden untuk pelanggan dan 25 responden untuk karyawan.

\section{Metode Analisis Data}

Model pengujian yang digunakan untuk menguji hipotesis dalam penelitian ini menggunakan analisis regresi berganda yang terdiri dari 4 pengujian yaitu uji simultan (bersama-sama), uji parsial (sendiri-sendiri), ujikorelasi, dan uji koefisien determinasi. Pengujian ini bertujuan untuk mengetahui pengaruh variabel independen terhadap kinerja organisasi Bank BRI Kanwil Makassar, dengan persamaan regresi yang digunakan untuk menguji hipotesis adalah :

Rumus :

$\mathrm{Y}=\mathrm{a}+\mathrm{b} 1 \mathrm{X} 1+\mathrm{b} 2 \mathrm{X} 2+\mathrm{b} 3 \mathrm{X} 3+\mathrm{b} 4 \mathrm{X} 4+\mathrm{e}$ Dimana: Kanwil Makassar 


\begin{tabular}{|c|c|}
\hline $\mathrm{a}$ & $=$ Konstanta \\
\hline b1,b2, b3,b4 & $=$ Koefisien Regresi \\
\hline $\mathrm{X} 1$ & $=$ Perspektif Keuangan \\
\hline $\mathrm{X} 2$ & $=$ Perspektif Pelanggan \\
\hline X3 & $=$ Perspektif Bisnis Internal \\
\hline $\mathrm{X} 4$ & $\begin{aligned}= & \text { Perspektif Pembelajaran dan } \\
& \text { Pertumbuhan }\end{aligned}$ \\
\hline
\end{tabular}

(Disturbance Error)

\section{HASIL DAN PEMBAHASAN \\ Hasil Analisis Data \\ Koefisien Determinasi (R2)}

Nilai koefisien determinasi yang didapatkan dari hasil pengolahan data pada penelitian ini sebagai berikut

\begin{tabular}{|c|c|c|c|c|}
\hline \multicolumn{5}{|c|}{ Tabel 3.1 Koefisien Deterninasi } \\
\hline Nodel & $R$ & RSgazre & Adjusted R Syzuare & Std Ensr of the Estimate \\
\hline 1 & $60]^{\mathrm{g}}$ & 363 & 306 & \begin{tabular}{l|l}
$5366 ?$ \\
\end{tabular} \\
\hline
\end{tabular}

Dari tabel diatas dapat diketahui bahwa nilai Adjusted $\mathrm{R}$ Square yang digunakan untuk mengukur seberapa jauh kemampuan model dalam menerangkan variasi variabel dependen adalah 0,603. Hal ini menunjukkan bahwa sebesar $60,3 \%$ Kinerja PT. Bank BRI melalui pendekatan Balance Score Card dipengaruhi oleh variasi dari keempat variabel independen, yaitu Perspektif Keuangan (X1), Perspektif Pelanggan (X2), Perspektif Bisnis Internal (X3), dan Perspektif Pertumbuhan dan Pembelajaran (X4) ,sedangkan sisanya sebesar 30,7\% dipengaruhi oleh variabelvariabel lainnya yang tidak diteliti dalam penelitian ini.

Untuk lebih jelasnya dapat dilakukan penilaian ke 4 jenis kinerja dengan balanced scorecard khususnya pada PT Bank BRI yaitu sebagai berikut :

\section{Perspektif Keuangan}

Analisis perspektif keuangan bertujuan untuk memenuhi harapan stakeholder, hal ini dilakukan dengan cara memperbaiki kinerja operasional perusahaan yang berdampak terhadap peningkatan laba dari setiap kinerja operasinya perusahaan. Alat analisis yang digunakan dalam menilai perspektif keuangan menurut Mulyadi (2001
: 135) khususnya pada PT. Bank BRI yaitu sebagai berikut :

1. Return on Asset (ROA)

Berdasarkan laporan keuangan yang diperoleh dari PT. Bank BRI, maka besarnya ROA untuk tahun 2013 - 2015 dapat ditentukan sebagai berikut :

Tabel 3.2 Hasil Perhitungan Return Of Asset (ROA)

\begin{tabular}{cccc}
\hline Tahun & Laba Bersih Setelah Pajak $\left(\mathrm{R}_{\mathrm{p}}\right)$ & Total Aktiva (Rp) & R0A(\%) \\
\hline 2013 & 30.827 .859 .439 & 1.003 .599 .812 .035 & 3.07 \\
\hline 2014 & 52.256 .112592 & 1.015 .592 .252 .051 & 5.15 \\
\hline 2015 & 61.847 .860 .522 & 1.174 .343 .229 .049 & 527 \\
\hline
\end{tabular}

Sumber: Data diolah, 2018

Berdasarkan tabel 3.2, hasil perhitungan return on asset (ROA) selama 3 tahun terakhir yang menunjukkan bahwa setiap Rp. 1,- aktiva yang diinvestasikan dapat memperoleh laba (profit) sebesar 3,07\% untuk tahun 2013, tahun 2015 sebesar $5,15 \%$ dan tahun 2015 sebesar $5,27 \%$. Dari hasil ROA yang dicapai oleh perusahaan untuk setiap tahun meningkat karena adanya kenaikan laba yang dicapai oleh perusahaan setiap tahunnya.

2. Return on Equity (ROE)

Berdasarkan laporan keuangan yang diperoleh dari PT. Bank BRI, maka besarnya ROE untuk tahun 2013 - 2015 dapat ditentukan sebagai berikut :

$$
\begin{aligned}
\square \square \square 2013= & \frac{30.827 .859 .439}{362.338 .447 .550} \times 100 \% \\
& =8.51 \% \\
\square \square \square 2014= & \frac{52.256 .112 .592}{310.082 .334 .958} \times 100 \% \\
& =16.85 \% \\
\square \square \square 2015= & \frac{61.847 .860 .522}{248.234 .474 .436} \times 100 \% \\
= & 24.92 \%
\end{aligned}
$$

Dari hasil ROE yang dicapai oleh perusahaan untuk setiap tahun meningkat karena adanya kenaikan laba yang dicapai oleh perusahaan setiap tahunnya. 


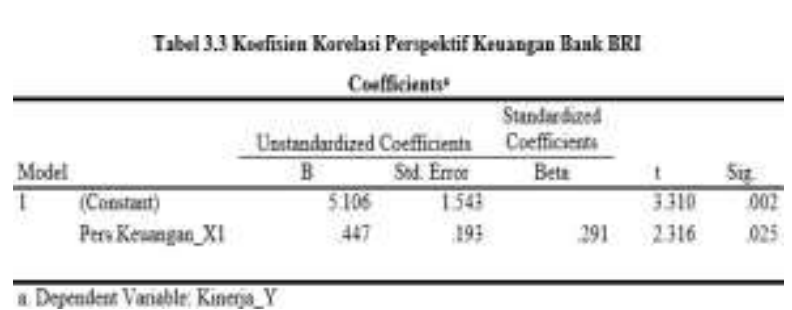

Dari tabel 3.3, dinyatakan bahwa perspektif keuangan PT. Bank BRI dari hasil olah data melalui sebaran kuesioner adalah berpengaruh signifikan terhadap Kinerja Bank BRI yaitu sebesar 0.025 pada level Signifikan $\mathrm{P}<0.05$.

Berdasarkan hasil perhitungan dengan rasio ROA \& ROE dinyatakan bahwa adanya peningkatan dari tahun 2013 - 2015, sehingga hasil yang didapatkan sesuai dengan perspektif keuangan maupun melalui hasil sebaran kuesioner yaitu memperoleh hasil yang sangat baik.

\section{Perspektif Pelanggan}

Berikut di cantumkan dari tabel 6 mengenai Perspektif Pelanggan Terhadap Kinerja PT. Bank BRI melalui sebaran kuesioner dan olah data sebagai berikut :

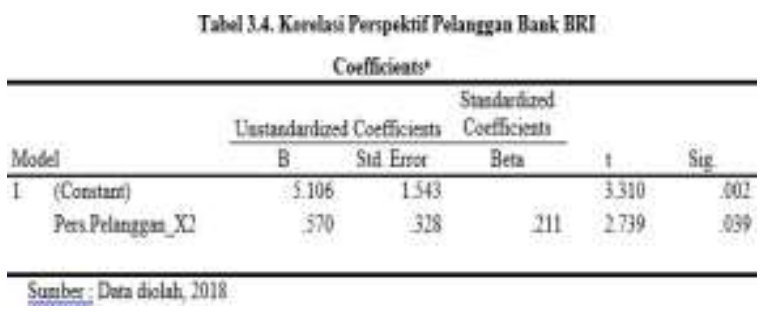

Dari tabel 3.4 dinyatakan bahwa perspektif Pelanggan terhadap PT. Bank BRI dari hasil olah data melalui sebaran kuesioner adalah berpengaruh signifikan yaitu sebesar 0.039 pada level Signifikan $P<0.05$. Hasil ini menunjukkan bawah perspektif pelanggan terhadap bank BRI adalah sangat baik atau dengan kata lain bahwa Perspektif Pelanggan mempengaruhi Kinerja Bank BRI.

\section{Perspektif Bisnis Internal}

Analisis perspektif proses bisnis internal bertujuan untuk mengukur perspektif pola produksi serta kinerja operasi dari PT. Bank BRI. Adapun pengukuran persepsi ini melalui sebaran kuesioner sebagaimana yang dicantumkan pada tabel 7 :

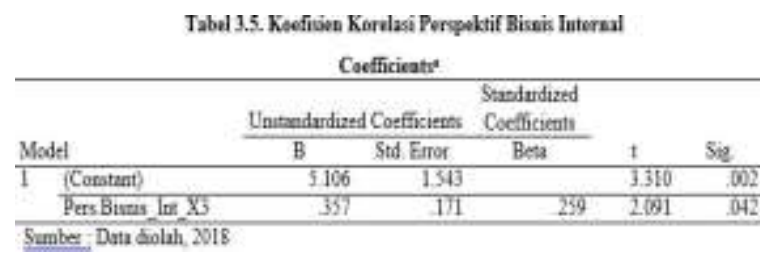

Dari tabel 3.5 dinyatakan bahwa perspektif Bisnis Internal PT. Bank BRI dari hasil olah data melalui sebaran kuesioner adalah berpengaruh signifikan yaitu sebesar 0.042 pada level Signifikan $\mathrm{P}<0.05$. Hasil ini menunjukkan bawah perspektif bisnis terhadap bank BRI adalah sangat baik atau dengan kata lain bahwa Perspektif Bisnis Internal yang dilakukan oleh PT. Bank BRI adalah sangat baik dan memuaskan.

\section{Perspektif Pertumbuhan dan Pembelajaran}

Dalam perspektif ini lebih banyak terpusat pada karyawan, dimana karyawan adalah salah satu sumber daya yang penting bagi perusahaan, karena tanpa karyawan maka akan mengakibatkan proses pelayanan tidak akan terlaksana. Adapun pengukuran persepsi ini melalui sebaran kuesioner sebagaimana yang dicantumkan pada tabel :

\begin{tabular}{|c|c|c|c|c|c|}
\hline \multicolumn{6}{|c|}{ Coefficients: } \\
\hline \multirow[b]{2}{*}{ Model } & \multicolumn{2}{|c|}{$\begin{array}{l}\text { Contandardized } \\
\text { Coeffikients }\end{array}$} & \multirow{2}{*}{$\begin{array}{l}\begin{array}{l}\text { Standandized } \\
\text { Cocflicients }\end{array} \\
\text { Bea }\end{array}$} & \multirow[b]{2}{*}{1} & \multirow[b]{2}{*}{ Sig: } \\
\hline & B & Sta Error & & & \\
\hline I (Consant) & 5.106 & 1543 & & 3310 & 002 \\
\hline Pers Petrminaian Xt & 281 & 129 & .282 & 2183 & 034 \\
\hline
\end{tabular}

\section{Uji Simultan (Uji F)}

Uji serempak atau uji $\mathrm{F}$ merupakan uji secara bersama-sama untuk menguji sigifikansi pengaruh variabel Perspektif Keuangan (X1), Perspektif Pelanggan (X2), Perspektif Bisnis Internal (X3), dan Persepektif Pertumbuhan dan Pembelajaran (X4) secara bersama-sama terhadap variabel Kinerja PT. Bank BRI (Y).Uji F dilakukan dengan membandingkan $\mathrm{F}$ hitung dengan $\mathrm{F}$ tabe 1. Hasil perhitungan olahdata disajikan pada tabel berikut ini : 


\begin{tabular}{|c|c|c|c|c|c|}
\hline \multicolumn{6}{|c|}{$\begin{array}{c}\text { Tabel } 37 \text { C Cj Simultan (CjiF) } \\
\text { AYOVA }\end{array}$} \\
\hline Model & Sun of Syuares & df & Mean Square & F & Sig \\
\hline 1 Regression & 1.43 & 4 & 1861 & 47.403 & $.000^{2}$ \\
\hline Residual & 13.053 & 45 & 290 & & \\
\hline Total & 20500 & 49 & & & \\
\hline
\end{tabular}

Berdasarkan hasil uji simultan dari tabel 9, ditunjukkan bahwa F hitung sebesar 47,403 sedangkan hasil Ftabel pada tabel distribusi dengan tingkat kesalahan (Margin Error 5\%) adalah sebesar 6,39. Hal ini berarti Fhitung > Ftabel $(47,403>6,39)$, dengan demikian diperoleh bahwa hipotesis yang menyatakan bahwa Perspektif Keuangan (X1), Perspektif Pelanggan (X2), Perspektif Bisnis Internal (X3), dan Persepektif Pertumbuhan dan Pembelajaran (X4). secara bersama-sama memiliki pengaruh yang signifikan terhadap terhadap variabel Kinerja PT. Bank BRI (Y) dengan nilai signifikansi $\mathrm{p}<0,05$ atau $0,000<$ 0,05 .

\section{Uji Parsial (Uji T)}

\begin{tabular}{|c|c|c|c|c|c|}
\hline \multirow[b]{3}{*}{ Model. } & \multicolumn{3}{|c|}{$\begin{array}{l}\text { Tabel 3.5. Uj Parsial (Cji T) } \\
\text { Coefficients }\end{array}$} & \multirow[b]{3}{*}{ t } & \multirow[b]{3}{*}{ Sit. } \\
\hline & \multicolumn{2}{|c|}{ Unstandrenhzed Coefficients } & $\begin{array}{l}\text { Standardizot } \\
\text { Coetficimits }\end{array}$ & & \\
\hline & $B$ & Sad Error & Bea & & \\
\hline (Consat) & 5.100 & 1547 & & 3,310 & 00. \\
\hline Pers_Kenargen_XI & 47) & 193 & 291 & 2.316 & 025 \\
\hline Pers Pehantgen_X2 & 570 & 328 & 211 & 2.739 & 039 \\
\hline Pers_Bisais_lat X3 & 357 & 171 & 259 & 2.091 & $04:$ \\
\hline Pess Pentumbutan X6 & 284 & 129 & $2 \mathrm{~K}_{2}$ & 2.153 & 054 \\
\hline
\end{tabular}

1. Variabel Perspektif Keuangan (X1) Nilai t hitung untuk variabel ini sebesar 2,316. Sementara itu nilai pada tabel distribusi 5\% sebesar 1,94318. Maka thitung $(2,316)>$ ttabel $(1,943)$ dan nilai signifikansi $(0,000<0,05)$ artinya variabel Perspektif Keuangan (X1) berpengaruh positif dan signifikan terhadap Kinerja PT. Bank BRI.

2. Variabel Perspektif Pelanggan (X2) Nilai t hitung untuk variabel ini sebesar 2,376. Sementara itu nilai pada tabel distribusi 5\% sebesar 1,01505. Maka thitung $(2,379)>$ ttabel $(1,015)$ dan nilai signifikansi $(0,000<0,05)$ artinya variabel Perspektif Pelanggan (X2) berpengaruh positif dan signifikan terhadap Kinerja PT. Bank BRI.

3. Variabel Perspektif Bisnis Internal (X3) Nilai t hitung untuk variabel ini sebesar 2,091. Sementara itu nilai pada tabel distribusi 5\% sebesar 1,31375. Maka thitung $(2,091)<$ ttabel $(1,313)$ dan nilai signifikansi $(2,091<0,05)$ artinya variabel Perspektif Bisnis Internal (X2) berpengaruh positif dan signifikan terhadap Kinerja PT. Bank BRI.

4. Variabel Perspektif Pertumbuhan dan Pembelajaran (X4)

Nilai t hitung untuk variabel ini sebesar 2,183 . Sementara itu nilai pada tabel distribusi 5\% sebesar 1,13185. Maka thitung 2,183) > ttabel $(1,131)$ dan nilai signifikansi $(0,000<0,05)$ artinya variabel perspektif Pertumbuhan dan Pembelajaran (X4) berpengaruh positif dan signifikan terhadap keputusan pembelian.

Berdasarkan penjelasan tersebut maka untuk menjawab hipotesis adalah sebagai berikut :

1. Perspektif Keuangan berpengaruh positif dan signifikan terhadap Kinerja PT. Bank BRI adalah $\mathrm{H} 0=$ Diterima

2. Perspektif Pelanggan berpengaruh positif dan signifikan terhadap Kinerja PT. Bank BRI adalah $\mathrm{H} 0=$ Diterima

3. Perspektif Bisnis Internal Tempat berpengaruh positif dan signifikan terhadap Kinerja PT. Bank BRI H0 = Diterima

4. Perspektif Pertumbuhan dan Pembelajaran berpengaruh positif dan signifikan terhadap Kinerja PT. Bank BRI H0 = Diterima.

Setelah dilakukan pengujian hipotesis baik secara parsial maupun serempak, maka dapat dijelaskan hubungan kauslitas antara variabel independen $(\mathrm{X})$ terhadap variabel 
dependen (Y) dalam penelitian ini sebagai berikut :

\section{Pengaruh Perspektif Keuangan Terhadap Kinerja Secara Parsial \\ Keberhasilan suatu organisasi sangat} tergantung sejauhmana sumber daya manusia yang digunakan dapat berkontribusi dalam mencapai tujuan individu dan tujuan organisasi. Kinerja organisasi akan tercapai dengan baik sepanjang kinerja individu sumber daya manusia juga tercapai. Oleh karena kinerja organisasi merupakan akumulasi atau kumpulan dari kinerja individu sumber daya manusia. PT. Bank Rakyat Indonesia (Persero) Tbk Wilayah Makassar merupakan salah satu lembaga keuangan yang memiliki kontribusi dalam membangun perekonomian bangsa dan meningkatkan kesejahteraan masyarakat pada umumnya dan khususnya di daerah provinsi Sulawesi Selatan. Hal ini tercermin dari berbagai kebijakan-kebijakan dalam membangun kerja sama yang dilakukan dengan pihak-pihak terkait baik pemerintah, pelaku bisnis dan masyarakat. Penilaian kinerja yang didasarkan pada perspektif keuangan perusahaan bertujuan untuk memberikan informasi tentang bagaimana nilai perusahaan dimata stakeholders, apakah aktivitas perusahaan tersebut dapat memberi ekspektasi sebagaimana yang diinginkan stakeholders pda umumnya.

Dari hasil analisa data dengan model regresi menunjukkan bahwa terdapat pengaruh yang kuat dan signifikan antara presfektif keuangan dengan kinerja organisasi. Hal ini bermakna bahwa semakin baik pengelolaan keuangan dalam organisasi baik dari aspek return on assets (ROA) maupun return on equity (ROE) maka tingat kinerja perusahaan juga semakin baik. Dengan demikian penelitian ini sejalan dengan penelitian sebelumnya (Kaplan dan Norton, 1996).

Pendapat lain tentang bagaimana persfektif keuangan ini menjadi ukuran kinerja organisasi. Sebenarnya tujuan finansial menjadi fokus tujuan dan ukuran dari persfektif lainnya. Dimana setiap ukuran yang terjadi haruslah merupakan hubungan sebab akibat yang pada akhirnya akan meningkatkan kinerja keuangan. Oleh sebab itu tujuan dan ukuran finansial harus memainkan peran ganda, yakni ; menentukan kinerja finansial yang diharapkan dari strategi, dan menjadikan sasaran tujuan akhir dan ukuran persfektif scorecard lainnya. Pada umumnya kesalahan yang dilakukan oleh beberapa manajemen adalah mengabaikan hubungan antara tujuan finansial dengan tujuan non finansial perusahaan serta faktor yang terkait dengannya. Dalam persfektif keuangan mencoba menekankan pada hubungan finansial dengan tujuan non finansial yang pada akhirnya akan menciptakan wealth pada perusahaan. Oleh sebab itu ukuran dalam persfektif keuangan lebih banyak berbicara tentang bagaimana risk and return yang akan dilakukan maupun yang sudah dilakukan perusahaan.

Tujuan dan sasaran dari persfektif finansial berbeda antara satu perusahaan dengan perusahaan lainnya hal ini tergantung dari masing-masing kehidupan bisnisnya (stage of a bussines life cycle). Sehingga dengan demikian, dijadikannya persfektif finansial tetap menjadi perhatian dalam balance scorcard karena ukuran finansial merupakan ikhtiar dari konsekuensi ekonomi yang terjadi sebagai akibat keputusan dan tindakan ekonomi yang diambil.

Hasil penelitian ini berbeda dengan penelitian sebelumnya sebagaimana dilakukan oleh Muh. Basri GB (2014) dimana temuan penelitiannya menunjukkan bahwa perspektif keuangan khususnya Total Asset Turn Over (TATO), Profit Margin On Sales dan Sales Growth memberi Kontribusi yang baik. Sedangkan Return on Assets (ROA) dan Return On Equity (ROE) belum memberi kontribusi kinerja yang memadai. Keberhasilan yang dicapai perusahaan dalam meningkatkan kinerja tentunya tidak terlepas 
dari peran serta sumber daya manusia dalam hal ini adalah karyawan dan Mitra kerjanya (pelanggan)

2. Pengaruh Perspektif Pelanggan Terhadap Kinerja Secara Parsial

Sudah menjadi ketentuan bahwa jika perusahaan ingin maju dan berkembang sebagaimana yang diharapkan, maka perusahaan harus memberikan pelayanan yang prima kepada customer. Hal ini sesuai dengan istilah yang mengatakan bahwa pelanggan adalah ibarat seorang raja yang harus diperlakukan sebagai raja. Istilah ini memberi makna bahwa keberlangsungan kehidupan perusahaan sangat bergantung pada kemampuan memelihara pelanggannya menjadi setia dan loyal terhadap perusahaan. Salah satu cara adalah seberapa besar kemampuan perusahaan memberi kepuasan sesuai harapan pelanggan.

Oleh karena itu usaha perusahaan mewujudkan harapan dalam persfektif pelanggan perusahaan harus melakukan identifikasi dan segmen pasar yang akan dimasuki. Biasanya perusahaan memilih dua ukuran kelompok persfektif pelanggan. Kelompok ukuran pertama merupakan ukuran yang bersifat umum (generik), meliputi ; pangsa pasar, akuisis pelanggan, kepuasan pelanggan, dan profitabiliti pelanggan. Sedangkan ukuran kelompok yang kedua adalah merupakan faktor pendorong kinerja yakni pembeda (differentiator) hasil pelanggan.

Berdasarkan hasil analisa data menunjukkan bahwa secara parsial terdapat hubungan dan pengaruh yang kuat serta sigfikan antara variabel persfektif pelanggan dengan kinerja organisasi perusahaan dalam hal ini PT. Bank Rakyat Indonesia Tbk. Hal ini menunjukkan bahwa sumber daya manusia organisasi memiliki peran yang cukup besar dalam memberikan pelayanan serta meningkatkan kepuasan kepada pelanggan baik secara langsung maupun tidak langsung.
Upaya organisasi dalam menjaga dan memelihara agar pelanggan tetap loyal dan setia terhadap perusahaan adalah dengan cara memberikan berbagai fasilitas layanan antara lain, menempatkan ATM di berbagai tempat baik dalam kota seperti Mall, shoping center, Rumah Sakit, Kampus yang mudah terjangkau oleh pelanggan. Sedangkan fasilitas di luar kota biasanya berdekatan dengan pasar tradisional, Toko-toko, dan fasilitas publik lainnya. Selain itu untuk memenuhi kebutuhan pelanggan perusahaan juga menawarkan berbagai macam jenis produk, layanan informasi, kemudahan dalam mendapat kredit, dan terisitimewa adalah memberikan kepuasan kepada pelanggan. Semua bentuk layanan yang diberikan organisasi kepada pelanggan bertujuan untuk meningkatkan kinerja berdasarkan pendekatan balance scorcard. Dengan kata lain kinerja sumber daya manusia tidak hanya diukur seberapa besar keuntungan yang diperoleh dari sejumlah dana yang digolontorkan kepada pelanggan, tetapi lebih dari itu adalah bagaimana organisasi dan sumber daya manusia yang terlibat di dalamnya memberi kontribusi melalui pemberian layanan kepada pelanggan yang tidak hanya didasarkan pada sumber finansial tapi juga non finansialnya.

Berdasarkan hasil penelitian sebagaimana dikemukakan diatas sejalan dengan penelitian sebelumnya yang mengatakan bahwa ada korelasi dan determinasi antara variabel persfektif pelanggan terhadap peningkatan kinerja (Basri, 2015). Keberhasilan yang dicapai perusahaan dalam meningkatkan kinerja perusahaan tentunya tidak terlepas dari peran strategi dan peran sumber daya manusia yang dibangun berdasarkan visi misi perusahaan. Dengan demikian pelanggan adalah Mitra perusahaan yang tidak bisa diabaikan begitu saja.

3. Pengaruh Perspektif Bisnis Internal Terhadap Kinerja Secara Parsial

Kaplan dan Norton mengemukakan bahwa dalam proses bisnis 
Internal, manajer harus bisa mengidentifikasi proses internal dimana perusahaan harus melakukan dengan sebaik-baiknya karena proses Internal tersebut mempu nyai nilainilai yang diinginkan konsumen dan dapat memberikan pengembalian yang diharapkan oleh pemegang saham.

Ada dua perbedaan mendasarkan antara pengukuran tradisional dengan pendekatan balance scorecard dalam persfektif ini, yaitu dimana Pendekatan tradisional lebih menekankan pada pengawasan dan melakukan perbaikan terhadap proses yang ada dengan lebih memfokuskan pada variance report. Sebaliknya pada pendekatan balance scorecard, penekanannnya diletakkan pada penciptaan proses baru yang ditujukan pada customer and finansial objrctives. Adapun tahapan-tahapan dalam persfektif ini antara lain : Inovasi. Pada tahapan ini diawali dengan mengidentifikasi berbagai keinginan pelanggan yang ada dengan menciptakan produk maupun jasa yang diinginkan pelanggan. Selanjutnya, mengidentifikan dan menciptakan bentuk pasar baru dan pelanggan baru dengan pula produk dab jasa yang baru dengan maksud untuk memberikan kepuasan kepada pelanggan.

Dalam proses inovasi tersebut terdapat long ware of value meliputi bentuk produk dan jasa, bentuk pasar, targe harga, dan kesukaan pelanggan yang kemudian melakukan researce and development (R\&D) yaitu pengembangan dan penelitian yang dilakukan oleh bidang R \& D. Sehingga dalam tahap inovasi ini tolok ukur yang digunakan adalah besarnya produk-produk baru yang dihasilkan, lamanya waktu yang digunakan atau dibutuhkan untuk pengembangan suatu produk jika dibandingkan dengan perusahaan pesaing, besarnya biaya yang digunakan, dan sejumlah produk-produk baru yang dapat dikembangkan.

Selain inovasi sebagai salah satu tahapan penciptaan nilai, adalah proses operasi juga merupakan short wave dari penciptaan nilai dalam perusahaan. Kegiatan yang dilakukan dimulai dari menerima berbagai order dari para pelanggan dan menyelesaikannya dengan memberikan produk atau jasa kepada para pelanggan secar efesien, konsisten, dan timely delivery untuk produk atu jasa yang ada. Dengan demikian maka pada tahapan ini merupakan tahapan dimana perusahaan berupaya untuk memberikan solusi kepada para pelanggan dalam memenuhi kebutuhan dan keinginan pelanggan.

Tolak ukur yang digunakan terutama pada perusahaan-perusahaan yang menghasilkan barang-barang produk, adalah Manufacturing Cycle Effectiveniss (MCE), tingkat kerusakan produk pra penjualan, banyaknya bahan terbuang percuma, frekuensi Pengerjaan ulang produk sebagai akibat terjadinya kerusakan, banyaknya permintaan para pelanggan yang tidak dapat dipenuhi, penimpangan biaya produksi aktual terhadap biaya anggaran produksi serta tingkat efesiensi per kegiatan produksi. Selain kedua hal diatas, maka yang tidak kalah pentingnya adalah yang disebut Postbel Service. Postuble Service adalah suatu proses penyampaian produk atau jasa kepada pelanggan. Dimana pada tahapan ini perusahaan memberikan pelayanan kepada para pelanggan dengan memberi garansi dan aktivitas perbaikan, perlakuan terhadap defect dan return, proses Pembayaran seperti administrasi Credit Card, serta proses Collection and Invoicing.

Dari hasil analis data penelitian menunjukkan bahwa terhadap hubungan dan pengaruh signifikan antara variabel internal perspektif terhadap kinerja perusahaan dengan pendekatan balance scorcard. Penelitian ini tidak sejalan dengan penelitian yang dilakukan Muh. Basri (2014), yang mengatakan bahwa perspektif proses bisnis dan internal belum memberikan kinerja yang baik sebab MCE kurang dari 1. Sedangkan Mardatillah (2013) dalam temuannya menunjukkan bahwa terhadap hubungan yang signifikan antara perspektif internal terhadap 
peningkatan kinerja perusahaan melalui pendekatan balance scorecard. Dengan demikian hopotesis diterima.

4. Pengaruh Perspektif Pembelajaran dan Pertumbuhan Terhadap Kinerja Secara Parsial

Pada Persfektif yang keempat berkenaan dengan penilaian kinerja perusahaan melalui pendekatan balance scorecard dalam penelitian ini adalah persfektif pembelajaran dan pertumbuhan dengan maksud untuk mengetahui bagaimana proses bisnis yang dilakukan perusahaan dapat lebih bersifat dinamis dan lebih sensitif dalam menghadapi kondisi yang ada. Tujuan dari persfektif pembelajaran dan pertumbuhan adalah menyediakan inprastruktur untuk mendukung pencapaian tiga persfektif sebelumnya yakni (keuangan, pelanggan, dan bisnis internal), yang dapat mengungkapkan adanya kesenjangan antara kemampuan yang ada dari orang, sistem dan prosedur dengan apa yang dibutuhakn untuk mencapai suatu kinerja yang andal. Untuk memperkecil kesenjangan tersebut perusahaan harus melakukan investasi reskelling employes

Guna memenuhi keinginan sebagaimana dikemukakan diatas Kaplan dan Norton (1996) mengemukakan bahwa ada beberapa faktor yang harus diperhatikan yakni ; Karyawan, Kemampuan sistem informasi, dan keunggulan balance scorecard itu sendiri. Hal pertama yang harus diperhatikan adalah kepuasan karyawan dan produktivitas kerja karyawan. Untuk mengetahui seberapa besar tingkat kepuasan karyawan tersebut perlu dilakukan survei dengan melihat beberapa aspek antara lain keterlibatan dalam pengambilan keputusan, adanya pengakuan, akses untuk memperoleh informasi, dorongan untuk melakukan kreativitas dan inisiatif, serta dukungan dari atasan. Sedangkan tingkat produktivitas merupakan hasil dari pengaruh agregat peningkatan keahlian moral, inovasi, perbaikan proses internal, dan tingkat kepuasan konsumen. Tentu saja di dalam menilai produktivitas kerja setiap karyawan diperlukan pemantauan dan evaluasi secara terus menerus.

Kedua adalah kemampuan sistem informasi. Pada aspek ini perusahaan perlu memiliki prosedur informasi yang mudah dipahami dan mudah dijalankan. Tolok ukur yang sering digunakan adalah bahwa informasi yang dibutuhkan sangat mudah diperoleh dan didapatkan, tepat dan tidak memerlukan waktu yang lama untuk memperolehnya.

Ketiga adalah Keunggulan Balance Scorecard. Barbara Gunawan (2000) mengemukakan bahwa Balance Scorecard memiliki beberapa keunggulan jika dibandingkan dengan pengukuran kinerja tradisional lainnya yang hanya mengukur kinerja berdasarkan aspek persfektif keuangan saja. Aspek-aspek keunggulan yang dimaksud adalah sebagai berikut ; (1) Bersifat komprehensif ; Artinya, bahwa dalam pengukuran kinerja dimana Balance scorecard tidak hanya menekankan pada aspek yang bersifat kuantitatif saja, tetapi juga yang bersifat aspek kualitatif. Aspek finansial harus dilengkapi aspek lainnya seperti aspek customer, inovasi, dan market development, adalah merupakan pengukuran secara integral. Keempat perspekti menyediakan keseimbangan antara pengukuran eksternal seperti laba dan pada pengukuran internal seperti pengembangan produk baru. Keseimbangan ini menunjukkan adanya trade off yang dilakukan pimpinan terhadap ukuran-ukuran tersebut untuk mendorong pimpinan dalam mencapai tujuan tanpa membuat trade off diantara kunci-kunci sukses tersebut melalui empat macam perspektif. Oleh sebab itu balance scorecard merupakan alat pengukuran kinerja yang mampu memandang berbagai faktor lingkungan secara general; (2) Adaftif dan representatif terhadap perubahan lingkungan bisnis. Artinya bahwa pengukuran kinerja dengan Balance scorecard memberikan pedoman terhadap aspek custumer, inovasi dan pengembangan, learning terhadap 
customer dimana preferencinya yang selalu berubah; (3) Fokus terhadap tujuan perusahaan. Artinya bahwa dengan pengukuran kinerja berdasarkan balance scorecard perusahaan memiliki kemampuan untuk melakukan berbagai inovasi dan pengembangan seperti menciptakan produk baru akan meningkatkan nilai (value) perusahaan. Melalui Penciptaan produk baru tersebut, akan memberi nilai tambah bagi pelanggan, disamping itu juga melakukan efesiensi secara berkesinambungan, sehingga perusahaan dapat melakukan penetrasi pasar yang lebih luas yang Berdampak terhadap pada peningkatan revenue dan margin, growth yang pada akhirnya akan meningkatkan nilai pemegang saham.

Jika dihubungkan dengan hasil analisa data menunjukkan bahwa terdapat hubungan dan pengaruh yang signifikan antara variabel Perspektif pembelajaran dan pertumbuhan terhadap kinerja PT. Bank Rakyat Indonesia Tbk Pada kantor wilayah Makassar. Penelitian ini sejalan dengan penelitian yang dilakukan oleh Muh. Basri (2014) yang mengatakan bahwa terdapat korelasi dan determinasi yang signifikan antara perspektif pembelajaran dan pertumbuhan terhadap peningkatan kinerja perusahaan. Demikian halnya dengan Wenny Yohanes (2013) yang mengatakan bahwa pengukuran kinerja dengan pendekatan balance scorcard memberi solusi dalam mengatasi berbagai hambatan, selain itu berfungsi sebagai sistem manajemen yang dapat menerjemahkan misi dan strategi perusahaan baik pada level atas maupun pada level bawah.

\section{SIMPULAN DAN SARAN}

Hasil penelitian ini menemukan variable Perspektif Keuangan (X3) merupakan variabel yang paling dominan berpengaruh terhadap Kinerja Bank BRI (Y). Hubungan keeratan antar variabel $\mathrm{X}$ dan $\mathrm{Y}$ sangat kuat mengindikasikan bahwa variabel Perspektif Keuangan, Perspektif Pelanggan, Perspektif Bisnis Internal \& Perspektif Pertumbuhan dan
Pembelajaran memiliki pengaruh yang sangat signifikan $(96,4 \%)$ berpengaruh terhadap Kinerja Bank BRI (Y). Adapun kesimpulan teoritis adalah kesemua variabel berpengaruh signifikan dan sesuai dengan teori serta penelitian-penelitian terdahulu

Penelitian ini menyarankan perlunya peningkatan kualitas Perspektif Bisnis Internal dan Perspektif Pelanggan masih dirasa perlu untuk ditingkatkan, meskipun level signifikansinya dibawah 0,05 tapi hasil pengujian pada penelitian ini menunjukkan nilai signifikansi pada perspektif bisnis internal yaitu 0.49 sedangkan pada Perspektif Pelanggan yaitu 0.39 .

\section{DAFTAR RUJUKAN}

Kasmir. 2002. Bank \& Lembaga Keuangan Lainnya. Jakarta: PT Raja Grafindo Persada.

Kaplan, R. S., \& Norton, D. P. (1996). Linking the balanced scorecard to strategy. California management review, 39(1), 53-79.

Basri, Y. M. (2015). Pengukuran Kinerja Non Finansial Dalam Meningkatkan Kinerja Finansial: Study Literatur. Jurnal Akuntansi (Media Riset Akuntansi \& Keuangan), 3(2), 114-126.

Mardatillah, Y. I., Nasution, H., \& Ishak, A. (2013). Evaluasi Kinerja Manajemen Sumber Daya Manusia PT. Bank XYZ Dengan Human Resource Scorecard. Jurnal Teknik Industri USU, 1(1).

Gunawan, B. (2000). Menilai Kinerja dengan Balanced Scorecard. Jurnal Manajemen. No 145. September, Hal. 36,40 .

Yohanes, W., \& Pontjoharyo, W. (2013). Perancangan Balanced ScorecardLearning and Growth Perspective Untuk Mencapai Sustainable Growth Di PT. Yamaha Indonesia Motor Manufacturing-Bali. Calyptra, 2(2), 111. 